\title{
Parasitological and Molecular Detection of Babesiosis in Cattle and Buffalo in West and Central Java
}

\author{
D H Sawitri ${ }^{1, *}$, A H Wardhana ${ }^{1}$, F Ekawasti ${ }^{1}$, and D A Dewi ${ }^{2}$ \\ ${ }^{1}$ Indonesian Research Centre for Veterinary Science, Indonesian Agency for Agricultural Research and \\ Development, Bogor, Indonesia \\ ${ }^{2}$ Polytechnic of Agriculture Development Yogyakarta, Magelang-Indonesia \\ *Corresponding author. Email: dyah.haryuningtyas@gmail.com
}

\begin{abstract}
Babesia sp are the intra-erythrocytic protozoan parasite causes Bovine babesiosis. Babesia bovis and Babesia bigemina are two species that commonly infest cattle. A conventional parasitological technique is commonly used to diagnose Babesia sp. This technique, however, has limitations in subclinical infections. Polymerase chain reaction (PCR) has a high sensitivity and can identify parasites at much lower concentrations. The goal of this study was to detect $B$. bovis and $B$. bigemina in blood cattle and buffaloes from fields using the conventional Giemza Staining Thin Blood Smear method (GSTBS). In addition, the study compared the effectiveness of a single and duplex PCR in detecting parasites. One hundred and ninety-eight blood samples from cattle and buffalo were collected in Bogor (West Java), Pemalang, and Brebes (Central Java). The parasite's existence was determined using a thin blood smear. Furthermore, the PCR assay was employed with primers Bovar $2 \mathrm{~A}$ and $\mathrm{Bg} 3 / 4$ specific for B. bovis and B. bigemina, yielding amplified products of 166 and $689 \mathrm{bp}$, respectively. Based on parasitological findings, 14 of 198 blood samples (7.1\%) tested positive for Babesia sp. The results of a single PCR demonstrated that 21,21\% (42/198) of the samples were positive for B. bovis, whereas duplex PCR successfully identified B. bovis and B. bigemina in 72 samples $(36,36 \%)$. This finding indicated that duplex PCR is more efficient and cost-effective than GSTBS and single PCR for surveying babesiosis in epidemiological studies.
\end{abstract}

Keywords: Babesia bovis, Babesia bigemina, single PCR, duplex PCR, Thin blood smear.

\section{INTRODUCTION}

Tick-borne diseases (TBD) are a hemoprotozoa illness that poses a substantial threat to cattle production in tropical and subtropical countries, as well as having a considerable economic impact on farming communities. (1). Bovine babesiosis is one of these TBD caused by hemoprotozoa apicomplexa Babesia bigemina and Babesia bovis (family Babesiidae, order Piroplasmida). Bovine babesiosis is highly pathogenic, causing chronic to severe infections in cattle and buffaloes (2). This pathogen is mainly transmitted by Rhipicephalus (Boophilus) micro-plus tick (3). Rhipicephalus (Boophilus) micro-plus infects around $80 \%$ of bovines globally, resulting in annual economic losses approximately to 3,000 million dollars (4). Pathogens acting as agents of TBD are frequently found simultaneously in single host $(5,6)$. Common clinical manifestation of this diseases are fever, anemia, hemoglobinuria, weakness, decrease milk production, nervous sign and occasionally death (7). A single species parasite did not produce any distinctive symptoms (8).
Calves between the ages of 9 and 12 months of age are generally resistant, but calves under the age of 6 month of age are relatively susceptible (9). Symptoms of babesiosis in newborn calves were failure to suckle, a high fever, coffee-colored urine, jaundice, and deep shallow respiration (10). Cattle that recover from the first infections become carriers, which contribute significantly to infectious agent transmission via ticks and flies. Survived animals typically become carriers with low level parasitemia, which continually stimulates specific antibodies and protect the animals against the recurrence of infection (11-13).

The prevalent of Babesiosis reported were $19 \%$ in Egypt (7); 7,25\% in China (14); 11,1-12,5\% in Thailand (15); $36,1 \%$ in India (16) and $17-20 \%$ in Pakistan (2). According to Noor et al. (17), the examination by using GSTBS on cattle blood sample collected from several locations in Indonesia showed positive results for piroplasmosis including Babesia sp. Australia, Kenya, Zimbabwe, Tanzania, South Africa, China, India, Indonesia, and the Philippines are predicted to lose 0.6 to 
57.2 million US dollars each year due to babesiosis and anaplasmosis (18). Babesiosis is commonly diagnosed using parasitological techniques in Giemza staining thin blood smear (GSTBS) (16). This conventional method has a number of drawbacks. It takes time, is dependent on the number of parasites in the blood, and is difficult to differentiate parasite species due to their similar morphology (19). According to OIE (20), this method is only useful during the acute stage of the disease, when the number of intraerythrocytic parasites is usually sufficient to detect microscopically. In subclinical and chronic infection, more advanced and sensitive techniques such as nucleic acid base detection methods should be used to identify parasites with low parasitemia levels $(21,22)$.Additionally, multiplex PCR will make it more economical and efficient to detect multiple hemoprotozoa simultaneously in a single reaction (16).

The rapidity and sensitivity of this technique are suitable for epidemiological studies aimed at determining the prevalence of parasitic infections in a given area associated with transmission and evaluating parasitic infection treatment (8).A single reaction requiring a less complex method and a lower cost is required to detect multiple pathogens for the diagnosis and surveillance of TBD in endemic regions (8). The aims of this study were to detect $B$. bovis and B. bigemina in the blood of cattle and buffalo collected from the field using the parasitological method (thin blood smear) and molecular methods (single and duplex PCR).

\section{MATERIAL AND METHODS}

\subsection{Ethical statement}

All procedures in this study adhered to the ethical guidelines for the use of animal samples established by the Animal Welfare Committee of the Indonesian Agricultural Research and Development Agency. (No: Balitbangtan/ BBLITVET/Rm/01/2017).

\subsection{Blood sample Collection}

The survey collected 198 samples of animal blood (buffalo and cow) in the Kunak-Bogor district (West Java Province), Pemalang and Brebes districts (Central Java Province). The samples were taken from randomly selected male and female cattle and buffalo, both adults and calves, that appeared to be in good health.
Blood samples up to $3 \mathrm{ml}$ were collected from the jugular vein and placed in tubes containing EDTA for DNA extraction and preparation of thin blood smears. The blood samples were stored at $-20^{\circ} \mathrm{C}$ till further analysis.

\subsection{Conventional Method (Giemza staining thin blood smear (GSTBS))}

Thin blood smears were made immediately after peripheral blood collection. The blood smears were dried in the air, fixed in methanol absolute for 5 minutes, stained with Giemsa $10 \%$ for 30 minutes, and washed with distilled water. Using a binocular microscope with an oil-immersion lens, the stained blood smear was analyzed for the presence of $B$. bovis and $B$. bigemina (100 x magnification). A positive sample was defined as having piroplasm levels more than or equal to 1 (23).

\subsection{DNA Extraction}

Genomic DNA was extracted at the Laboratory of Molecular Parasitology, Indonesian Research Centre for Veterinary Science, Bogor, according to the manufacturer's instructions using a commercial DNA extraction kit (Geneaid, Taiwan). The extracted DNA samples were stored at $-20{ }^{\circ} \mathrm{C}$ pending further genetic analysis.

\subsection{Primers for Single and Duplex-PCR.}

The oligonucleotide primers used to establish single or duplex-PCR for B. bovis (Bovar 2A) and B. bigemina (Bg3/4) were designed to target the multi-copy VESA1 a gene for $B$. bovis and a small subunit ribosomal RNA sequence for B. bigemina, as described below (Table 1).

\subsection{Optimization Single and Duplex PCR}

The primer sequences reported by Wuyts et al and Ellis et al $(24,25)$ were utilized to amplify B. bovis and B. bigemina DNA using PCR methods. Positive control PCR optimization was performed on bovine / buffalo DNA samples detected via thin blood smear. PCR amplification was performed using Bioline (England) consisting of 5x My Taq Reaction Buffer $10 \mu \mathrm{l}$; My Taq HS DNA polymerase $1 \mu$, forward and reverse primers 2 $\mu 1$ each $(10 \mu \mathrm{M}) ; 2 \mu$ l DNA template (50-100ng) and 8 $\mu 1$ PCR grade water with a total reaction volume of $25 \mu \mathrm{l}$.

Table 1. Primer duplex PCR for B. bovis and B. bigemina

\begin{tabular}{|l|l|l|l|l|}
\hline \multicolumn{2}{|c}{ Hemoprotozoa } & \multicolumn{2}{c|}{ Primer } & Reference \\
\hline B. bovis & Bovar-2A & 5'- CAA GCA TAC AAC CAG GTG G - 3' & 166 & $(24)$ \\
\hline & & 5'-ACC CCA GGC ACA TCC AGC TA-3' & & \\
\hline B.bigemina & Bg3/4 & 5'-TAGTTGTATTTCAGCCTCGCG-3' & 689 & $(25)$ \\
\hline
\end{tabular}


Table 2. Giemza Staining Thin Blood Smear, single and duplex PCR of B. bovis and B. bigemina

\begin{tabular}{|c|l|l|c|c|c|}
\hline \multirow{2}{*}{ No } & \multirow{2}{*}{ Breed } & \multirow{2}{*}{$\mathrm{N}$} & \multicolumn{3}{|c|}{ Sample positive } \\
\cline { 4 - 6 } & & & $\begin{array}{c}\text { GSTBS Babesia } \\
\text { sp }\end{array}$ & $\begin{array}{c}\text { Single PCR } \\
\text { B. bovis }\end{array}$ & $\begin{array}{c}\text { Duplex PCR } \\
\text { B.bovis and B.bigemina }\end{array}$ \\
\hline 1 & Cow & 141 & 9 & 33 & 53 \\
\hline 2 & Buffalo & 57 & 5 & 9 & 19 \\
\hline & TOTAL & 198 & $7.07 \%(14 / 198)$ & $21.21 \%(42 / 198)$ & $36.36 \%(72 / 198)$ \\
\hline
\end{tabular}

Table 3. The result of PCR duplex of B. bigemina , B. bovis and co infection both in cattle and buffaloes

\begin{tabular}{|l|l|l|c|c|c|c|}
\hline No & Breed & N & Babesiosis & B.bovis & B. bigemina & $\begin{array}{c}\text { Mix B. bigemina } \\
\text { dan B. bovis }\end{array}$ \\
\hline 1 & Cow & 141 & 53 & 33 & 4 & 16 \\
\hline 2 & Buffalo & 57 & 19 & 9 & 7 & 3 \\
\hline & TOTAL & 198 & $36.36 \%(72 / 198)$ & $21.21 \%(42 / 198)$ & $5.55 \%(11 / 198)$ & $9.59 \%(19 / 198)$ \\
\hline
\end{tabular}

The PCR conditions used was initial denaturation at $95^{\circ} \mathrm{C}$ for 3 minutes was followed by 35 cycles of denaturation at $95^{\circ} \mathrm{C}$ for 15 seconds, annealing at $56^{\circ} \mathrm{C}$ for 15 seconds, extension at $72^{\circ} \mathrm{C}$ for 30 seconds, and the final extension at $72^{\circ} \mathrm{C}$ for 10 minutes. Electrophoresis on a $2 \%$ agarose gel was used to visualize the PCR results.

\section{RESULT AND DISCUSSION}

Babesiosis is one of vector-borne diseases that is prevalent throughout the tropics and subtropics, including Indonesia. According to the findings of this study, Babesiosis appears to be endemic in a number of Indonesian areas. Blood smear examination with giemza staining on buffalo and cattle blood samples collected in the field (Bogor, Brebes, and Pemalang) revealed 14 positive Babesia sp. samples out of 198 (Table 2). In this study, parasitemia was detected in blood samples using GSTBS at a level of $0.001-0.002 \%$ parasitized erythrocytes. Babesia species was identified based on its pyriform shape (Figure 1). Clinical symptoms were not detected in any of the animals sampled in the present study. Infested livestock tend to be subclinical. This is because it has a low parasitemia value (0,001-0,002\%). However, it is necessary to be aware that when an animal's immune is compromised, these parasites will multiply rapidly and cause serious illness. Although cattle infected with babesia rarely cause clinical symptoms, but they are economically detrimental because of their morbidity and decrease productivity in domestic animals $(26,27)$. According to Perry et al. (1998) stated which a state of "Endemic Stability" in Babesiosis where the relationship between parasite, vector, host and environment were interrelated that clinical symptom occur rarely or not at all need to be consider. Although babesia infections in cattle are uncommon, they are economically damaging due to their morbidity and decreased output in domestic animals $(26,27)$.

\subsection{Specificity of PCR Primers}

Positive control PCR amplified $B$. bovis and $B$. bigemina were identified using DNA extracted from field blood samples that tested positive for parasites on both blood smear and PCR examination. For B. bovis and $B$. bigemina, the specific primers detected expected fragments of size $166 \mathrm{bp}$ and $689 \mathrm{bp}$, respectively (Figure 2 ). To detect $B$. bovis and B. bigemina simultaneously, a duplex PCR was designed by combining two pairs of specific primers, Bovar 2A (166bp) for B. bovis and $\mathrm{Bg} 3 / 4$ (689bp) for B. bigemina in a single tube reaction. Using a specific primer for one parasite species, no PCR results from any other parasite species were produced. species. Additionally, the duplex PCR method using both sets of primers generates two bands from $B$. bovis and $B$. bigemina that are the same length as the one-round PCR. The PCR amplification of parasite isolates from various districts is consistent, as all isolates were amplified using the same set of primers.z

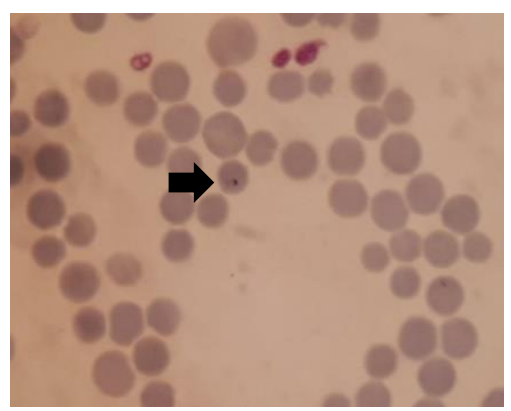

Figure 1. Babesia sp. on cattle thin blood smear Giemza staining from Bogor (100x magnification).

\subsection{PCR analysis of the field blood samples}

Babesia bovis is the most prevalent species in these three districts in Indonesia (Bogor, Pemalang and 
Brebes). Meanwhile, Babesia bovis and Babesia bigemina are the predominant species in bovines in endemic areas in India $(9,10)$, South Africa (29), Malaysia (30) and Thailand (31). The results of this study indicated that overall prevalence of Babesiosis in large ruminants at the three districts was $36.36 \%$ when duplex PCR was used, compared to a lower $21.21 \%$ when single PCR was applied and a much lower 7,07 percent when GSTBS was used (Table 2). Babesia bovis detection by single PCR is consistent with detection of B. bovis and $B$. bigemina by duplex PCR. In this study, the prevalence of single $B$. bovis infection $(21.21 \%$ ) was significantly higher than that of single $B$. bigemina infection $(5.55 \%)$ or mixed infection (9.59\%) (Table 3). This finding contrasted with those of Oliveira et al (32) and Adham et al. (33)who found that in all cattle groups, a higher positivity percentage was typically observed in cattle with mixed infection by more than one species, not only infected with $B$. bovis but also infected with $B$. bigemina concomitantly. A similar situation occurred in vectors in

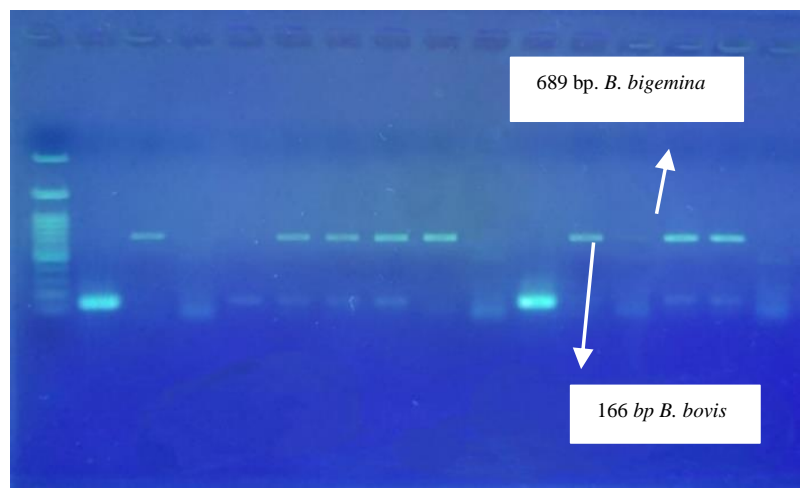

cattle of all ages, with a higher positivity percentage as determined by multiplex PCR.

Figure-2. Gel electrophoresis of duplex PCR products of cattle and buffalo blood samples with primer Bovar $2 \mathrm{~A}$ (166 bp) for B. bovis and $\mathrm{Bg} 2 / 3$ (689bp) for B. bigemina Lane 1 positive control; lane 3,9,12 B. bovis and $B$. bigemina negative, lane 4,10 B.bovis positive; lane $2,8,11$ $B$. bigemina positive; lane 5,6,7,13,14 mix B. bovis and $B$. bigemina positive; lane 13,14 B. bigemina positive; lane 15 negative control. The amplified products prepared from GSTBS positive and negative blood samples from the field.

Because $B$. bovis and B. bigemina infections exhibit nearly identical clinical signs and frequently co-occur in suitable tropical climatic conditions, it is critical to use a sensitive and specific technique to detect both diseases concurrently in suspected animals (16). The current study demonstrated that the PCR method detected more positive samples than the thin GSTBS method. Duplex PCR, on the other hand, was more sensitive than single PCR or the conventional method. Additionally, several PCR-positive samples were found to be negative on blood smear (false negative), which could be due to the blood smear diagnostic method's inefficiency in distinguishing some Babesia species, which are frequently confused for other piroplasm or blood smear artifact. According to Terkawi et al. (29) the gold standard test for diagnosing Babesiosis is a direct method of identifying the parasite in the GSTBS, although this technique is insensitive during the subclinical and chronic phases of infection due to low parasitemia levels. Molecular method can detect and differentiate Babesia sp. when conventional methods are taken, the morphological characteristics of babesias are very similar, making differentiation difficult, even more particularly when co-infection occurs.

The detection of B. bovis and B. bigemina in blood samples using blood smears revealed approximately $0.001-0.002 \%$ parasitized erythrocytes in this study. Oliveira et al. (32) estimated that the analytical sensitivity of PCR for B. bigemina was $0.003 \%$ for B. bovis and $0.000017 \%$ for B. bigemina. According to Liu et al. (34) The single-round Multiplex PCR of B. bigemina and $B$. bovis primers could detect $0.1 \mathrm{pg}$ and $1 \mathrm{pg}$ of DNA in the samples, respectively.

A previous study conducted by Mclaughlin et al. (35) demonstrated that the multiplex PCR was able to detect 1 $\mathrm{pg}$ and $10 \mathrm{pg}$ of DNA respectively, comprising DNA from $B$. bigemina and $B$. bovis equal to the amount of DNA in $50 \mu 1$ of $0.0001 \%$ and $0.001 \%$ parasite-infected erythrocytes. Babesia $s p$. was shown to be prevalent in all age groups of animals in this investigation. The incidence rate is lower in young animals than in older animals (Figure-3).

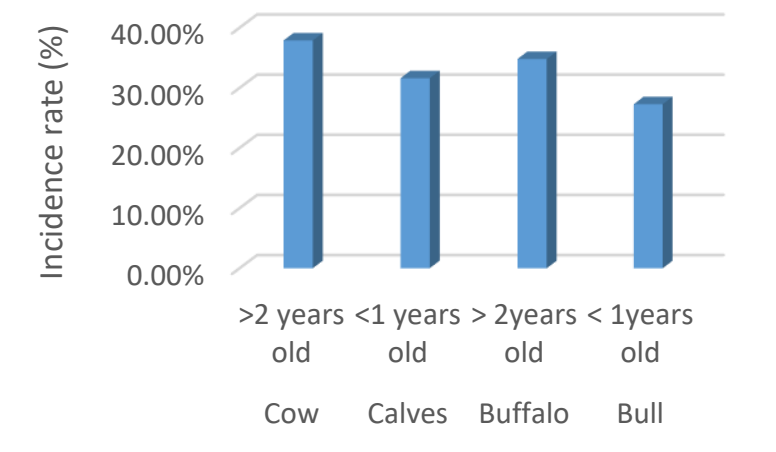

Figure-3. Distribution Babesiosis (B. bigemina and $B$. bovis) infection of cattle and buffalos based on animal age by using duplex PCR methods.

Overall, the highest prevalence of babesiosis in terms of age was detected by PCR in older animals (greater than two years of age) compared to younger animals (less than one year of age) on both cattle and buffalo. Calves between the ages of 9 and 12 months are generally resistant, but calves under the age of 6 months are relatively susceptible (9). Cattle in endemic areas, according to the OIE (36) become infected at an early age and develop long-lasting immunity. When young animals are exposed to ticks or susceptible cattle are introduced into these endemic areas, outbreaks can ensue. Disease 
outbreaks may also result in the introduction of Babesiainfected ticks into previously tick-free areas.

\section{CONCLUSION}

DNA amplification technique employing duplex PCR results in a 1,6x increase in amplification efficiency over single PCR and a 5x increase in efficiency over microscopic method. In endemic area of study, the incidence of $B$. bovis infection is significantly higher than that of $B$. bigemina infection or co infection. Diagnosis Babesiosis can be diagnosed using parasitological examination (thin blood smear) in conjunction with polymerase chain reaction (PCR) methods to increase sensitivity. Duplex PCR is required to detect co-infection and to minimize false negatives, considering that infested animals rarely cause clinical symptoms but can act as a reservoir that has the potential to transmit the disease from one area to another.

\section{ACKNOWLEDGMENT}

The Indonesian Agency for Agricultural Research and Development, Ministry of Agriculture funded this study in part through the 2017 National Budget.

\section{AUTHOR CONTRIBUTION}

There is no conflict of interest in writing this manuscript. The main authors of the manuscript are DH Sawitri. AH Wardana, F Ekawasti and DA Dewi as co-authors. All authors had read and approved the final manuscript.

\section{REFERENCES}

[1] Canever M, Vieira L, Reck C, Richter L, LC M. First Evaluation of an outbreak of bovine babesio- sis and anaplasmosis in southern Brazil using multiplex PCR. Korean JParasitol. 2014;52:507-11.

[2] Khetran IB, Arijo AG, Buhtto MB, Ali J. Prevalence and molecular detection of Babesia bigemina in water buffalo from southeastern region of Pakistan. 2019;(June).

[3] Ravindran R, Rao J, Mishra A. Detection of Babesia bigemina DNA in ticks by DNA hybridization using a nonradioactive probe generated by arbitrary PCR. Vet. Parasitol. 141(1/2):181-185. Vet Parasitol. 2006;141(1/2):181-5.

[4] Melendez R, Forlano M. Incidence and intensity of Babesia spp. sporokinetes in engorged Boophilus microplus from a dairy herd in Venezuela. Ann NY Acad Sci. 1996;791:148-56.

[5] Gubbels JM, de Vos A., van der WM, Viseras J, Schouls LM, de Vries E, et al. Simultaneous detection of bovine Theileria and Babesia species by reverse line blot hybridization. J Clin Microbiol. 1999;37:1782-9.
[6] Simuunza M, Weir W, Courcier E, Tait A, Shiels B. Epidemiological analysis of tick-borne diseases in Zambia. Vet Parasitol 175, 331-342. 2011;175:33142.

[7] Al-Hosary A. Loop-Mediated Isothermal Amplification ( LAMP ) Assay for Diagnosis of Bovine Babesiosis ( Babesia bovis infection ) in Egypt. 2017;7(3):71-4.

[8] Bilgiç HB, Karagenç T, Simuunza M, Shiels B, Tait A, Eren $\mathrm{H}$, et al. Development of a multiplex PCR assay for simultaneous detection of Theileria annulata, Babesia bovis and Anaplasma marginale in cattle. Exp Parasitol. 2013;133(2):222-9.

[9] Karunakaran S, Pillai U, Narayana, KAM Aswathy G, Rajimon K, Sumangala M. Babesia bigemina infection in a twenty day old calf. J Indian Vet Assoc Kerala. 2011;9:49-50.

[10] Venu R, Sailaja N, Rao K, Jayasree N, Rasad W. Babesia bigemina infection in a 14 day old Jersey crossbred calf: A case report. J Parasit Dis. 2013;

[11] Homer M, Aguilar-Delfin I, Telford S, Krause P, Persing D. Babesiosis. Clinical Microbiology 13, 451-469. Clin Microbiol. 2000;13:451-69.

[12] Radostitis O, Gay C, Blood D, Hinchcliff K. Text book of Veterinary Medicine. 9th Edn. 9th Edn. Baieller Tindal and Co, pp.; 2010. 1328-1329 p.

[13] Mosqueda J, Olvera-Ramírez A, Aguilar-Tipacamú G, Cantó G. Current Advances in Detection and Treatment of Babesiosis. Curr Med Chem. 2012;19:1504-18.

[14] Zhou Z, Li K, Sun Y, Shi J, Li H, Chen Y. Molecular epidemiology and risk factors of Anaplasma spp., Babesia spp. And Theileria spp. infection in cattle in Chongqing, China (PLoS ONE (2019) 14:7(e0215585) Doi: 10.1371/journal.pone.0215585). PLoS One. 2019;14(8):1-11.

[15] Jirapattharasate C, Adjou Moumouni PF, Cao S, Iguchi A, Liu M, Wang G, et al. Molecular detection and genetic diversity of bovine Babesia spp., Theileria orientalis, and Anaplasma marginale in beef cattle in Thailand. Parasitol Res [Internet]. 2017;116(2):751-62. Available from: http://dx.doi.org/10.1007/s00436-016-5345-2

[16] Sharma A, Singla L, Tuli A, Kaur P, Batth B, Javed $\mathrm{M}$, et al. Molecular prevalence of babesia bigemina and trypanosoma evansi in dairy animals from Punjab, India, by duplex PCR: A step forward to the detection and management of concurrent latent infections. Biomed Res Int. 2013;2013:1-8.

[17] Noor S, Sawitri D, Saepulloh M, Aji R, Desem M, Azmi Z. Profil Kesehatan Sapi Indukan Belgian 
Blue di Indonesia terhadap Penyakit Hewan Menular. Pros Semin Nas Teknol Peternak dan Vet. 2019;191-200.

[18] Bock R, Jackson L, De Vos A, Jorgensen W. Babesiosis of cattle. Parasitology. 2004;129(SUPPL.).

[19] Uilenberg G. A field guide for the diagnosis, treatment and prevention of African animal Animal Trypanosomes. In: FAO Corporate Document Repository. Agriculture Costumer Production; 1998.

[20] OIE. Bovine Anaplasmosis. In: Manual of Diagnostic Tests and Vaccines for Terrestrial Animals. 6th ed. Paris: World Organisation for Animal Health; 2008. p. 599-610.

[21] Figueroa J, Chieves L, Johnson G, Buening G. Multiplex polymerase chain reaction based assay for the detection of Babesia bigemina, Babesia bovis and Anaplasma marginale DNA in bovine blood. Vet Parasitol. 1993;50(1-2):69-81.

[22] AL-Hosary AA. Comparison between Conventional and Mo- lecular Methods for Detection of Bovine Babesiosis (Babesia bovis infection) in Tick Infested Cattle in Upper Egypt. J Parasit Dis. 2016;1-4.

[23] Salih DA, El Hussein AM, Seitzer U, Ahmed JS. Epidemiological studies on tick-borne diseases of cattle in Central Equatoria State, Southern Sudan. Parasitol Res. 2007;101(4):1035-44.

[24] Wuyts N, Chokesajjawatee N, Panyim S. A simplified and highly sensitive detection of Trypanosoma evansi by DNA amplification. Southeast Asian J Trop Med Public Health. 1994;25(2):266-71.

[25] Ellis J, Hefford C, Baverstock P, Dalrymple B, Johnson A. Ribosomal DNA sequence comparison ofBabesia and Theileria. Mol Biochem Parasitol. 1992;54(1):87-95.

[26] Gharbi M, Sassi L, Dorchies P, Darghouth MA. Infection of calves with Theileria annulata in Tunisia: economic analysis and evaluation of the potential benefit of vaccination. Vet Parasitol. 2006;137:23141.

[27] Uilenberg G. International collaborative research: significance of tick-borne hemoparasitic diseases to world animal health. Vet Parasitol. 1995;57(13):19-41.

[28] Perry B, Chamboko T, Mahan S, Medley G, Minjauw B, O'Callaghan C. The economics of integrated tick and borne diseases control on commercial farms in Zimbabwe. Zimb Vet J. 1998;29:21-9.

[29] Terkawi M, Thekisoe O, Katsande C, Latiff A, Mans B, Matthee O, et al. Serological survey of Babesia bovis and Babesia bigemina in cattle in South Africa. Vet Parasitol, 182 337-342. 2011;182:337-42.

[30] Rahman WA, Lye YP, Chandrawathani P. The seroprevalence of bovine babesiosis in Malaysia. Trop Biomed. 2010;27(2):301-7.

[31] Terkawi M, Huyen N, Shinuo C, Inpankaew T, Maklon K, Aboulaila M, et al. Molecular and serological prevalence of Babesia bovis and Babesia bigemina in water buffaloes in the northeast region of Thailand. Vet Parasitol [Internet]. 2011;178(34):201-7. Available from: http://dx.doi.org/10.1016/j.vetpar.2011.01.041

[32] Oliveira MCS, Oliveira-Sequeira TCG, Araujo JP, Amarante AFT, Oliveira HN. Babesia spp. infection in Boophilus microplus engorged females and eggs in São Paulo State, Brazil. Vet Parasitol. 2005;130(1-2):61-7.

[33] Adham F, Abd-El-Samie E, Gabre R, El Hussein H. Detection of tick blood parasites in Egypt using PCR assay I-Babesia bovis and Babesia bigemina. Parasitol Res. 2009;105(3):721-30.

[34] Liu J, Guan G, Liu A, Li Y, Yin H, Luo J. A PCR method targeting internal transcribed spacers: The simultaneous detection of Babesia bigemina and Babesia bovis in cattle. Acta Parasitol 2014;59(1):132-8.

[35] Mclaughlin G, Edlind T, Ihler G. Detection of Babesia bovis using DNA hybridization. J Protozool. 1986;33:125-8.

[36] OIE. Bovine Babesiosis: Aetioloy Epidemiologi Diagnosis Prevention and Control References. World Organisation for Animal Health. 2013. 